\title{
Prevalence of Rota Virus Detection by Reverse Transcriptase- Polymerase Chain Reaction in Stool from Children Fewer Than Five Age With Acute Diarrhea in Diyala Province in Iraq
}

\author{
Ansam Dawod Salman \\ Lecturer in Diyala University, Collage of science, Department of Biology
}

\begin{abstract}
The present study was conducted for the period from 1/6/2016 to 20/1/2017 in Baquba city. The study aimed to detection of rotavirus in stool specimens of children fewer than five age and also explore the effects of certain demographic factors on the detection rates by revers transcriptase-polymerase chain reaction. The study included 49 patients with acute diarrhea, 32 were male and 17 were female. The age range was two months to 5 years. Demographic information on the patients regarding age, sex, residence, type of feeding and source of drinking water were collected from their parents. Stool specimens were collected from each patients and. Detection of rotavirus in stool specimens was done by conventional reverse transcriptase polymerase chain reaction (RT-PCR). The results of present study showed that the overall infection rate by rotavirus among patients with acute diarrhea by RT-PCR tests was $93.88 \%$. The highest infection rate was recorded among those $>10-\leq 15$ months of age. None of the results showed significantly difference between female and male, PCR (88\% vs 96.87\%). Likewise, there was insignificantly difference between urban and rural residence, PCR (95.65\% vs 92.30\%). The results revealed insignificantly higher infection rate among patients (those below 2 years) feed mixing $(91.66 \%)$ and bottled (100\%) compared to that breast feeding $(77.77 \%)$ by RT-PCR. The rotavirus infection rate was insignificantly higher among patients consuming municipal water for drinking (97.22\%) compared to those consuming bottled water (84.61\%) by the RT-PCR. The study concluded that rotavirus was detected in high rates among children less than 5 years old with acute diarrhea in Baquba city, particularly those less than 2 year old.
\end{abstract}

Keywords: Rotavirus, RT-PCR, diarrhea.

\section{Introduction}

The RV belongs to the Reoviridae family, exhibits icosahedral symmetry; it is not enveloped and was first identified by electron microscopy by Bishop et al. $(1993)^{(1)}$. The viral particle consists of three layers of protein and the viral genome consists of 11 segments of double-stranded RNA (dsRNA), which encode six structural proteins, VP1-4, VP6 and VP7 and six non-structural proteins, NSP1-6 ${ }^{(2)}$. The VP6 protein, located in the inner capsid of the virus contains the antigenic determinants, which allow their classification into seven serogroups of A to $\mathrm{G}$, with group A being the most common agent of childhood diarrhea ${ }^{(3)}$. At present, 5 rotavirus serotypes (G1, G2, G3, G4, G9) are the predominant circulating strains, accounting for approximately $95 \%$ of strains worldwide, although there is considerable geographic variability ${ }^{(4)}$ and 5$)$.

Today, Rotaviruses are recognized as the single most significant cause of severe gastroenteritis, malnutrition and diarrhea in young children in both developed and developing countries worldwide ${ }^{(6)}$. Although $\mathrm{RV}$ can infect older children and adults, diarrheal disease is primarily observed in children under 2 years of age ${ }^{(7)}$. It accounts for $5 \%$ of all deaths in children younger than 5 years in developing countries. Mortality rates in developed countries on the other hand are very low and illness is usually self limiting ${ }^{(8 \text { and } 9)}$.

RVs are transmitted by fecal-oral spread, and possibly also by the respiratory route ${ }^{(10)}$. It has an incubation period of 18-36 hours. Following ingestion, the virus attaches to and then replicates in the differentiated villous columnar epithelial cells (enterocytes) lining the upper small intestine. Death and desquamation of infected enterocytes impairs the normal digestive and absorptive processes, outcomes a watery diarrhea of 2-7 days duration, resulting in loss of fluids and electrolytes, which may lead to severe or fatal dehydration. Rotavirus induced diarrhea is thought to be caused by a combination of factors ${ }^{(11)}$, which include a reduction in epithelial surface area, replacement of mature enterocytes by immature cells, an osmotic effect resulting from incomplete absorption of carbohydrates from the intestinal lumen with bacterial fermentation of these non-absorbed compounds, secretion of intestinal fluid and electrolytes through activation of the enteric nervous system ${ }^{(12 \text { and } 13)}$, and the effect of the RV non-structural protein 4 (NSP4), which is thought to act as a viral enterotoxin ${ }^{(14)}$. 
Initially, diagnosis of rotavirus infection was performed using electron microscopy, by visualization and observation of the rotavirus wheel-like appearance ${ }^{(15)}$. Nowadays, the laboratory diagnosis of rotavirus infection is usually performed by antigen detection, using latex agglutination techniques, which is affirmed to be a good tool for the simple and rapid detection of RV in stool specimens ${ }^{\text {(16 and } 17)}$. Enzyme-linked immunosorbant assays which are the most preferably used due to their high sensitivity and specificity for detection of RV in different pathological specimens ${ }^{(18 \text { and 19) }}$. More sensitive and newer methods are molecular techniques such as polyacrylamide gel electrophoresis (PAGE) and reverse transcription-polymerase chain reaction (RT-PCR), which are used to determine the RV-RNA migration patterns and virus genotyping, respectively ${ }^{(20)}$.

\section{Study groups:}

\section{Materials and Methods}

The present study was conducted in Baquba city for the period from 1/6/2016 to 20/1/2017. The group of study were included; 49 patients with acute diarrhea. The patients were attended Al-Batool Maternity and Children Teaching Hospital and the following Primary Health Care Centers in Baquba (Al-Takea, Al-Sarai and Al-Tahrer). 32 of patients were males and 17 were females. The age range was 2 months to 5 years. Special questionnaire was pre-constructed to collect information regarding age, sex, residence, type of feeding and source of drinking water. The information was collected through short personal interview with patient's parents.

\section{Collection of stool specimens:}

Forty nine stool specimens were collected from patients were diagnosed by the doctor with disposable clean containers with tightly fixed caps. The specimens were transferred to the laboratory of Al-Batool Maternity and Children Teaching Hospital in a cool box as soon as possible. The PCR technique was carried out at Virology Laboratory/ College of Veterinary Medicine- Diyala University.

\section{Molecular detection of rotavirus: RNA extraction: \\ RT-PCR test:}

This test was performed using commercially available kit (Sacace Biotechnologies / Rotavirus 280 PCR kit).

Test principle:

The test principle of the kit rotavirus 280 was based on four major processes: isolation of rotavirus RNA from specimens, reverse transcription of the RNA, amplification of the cDNA and detection of the amplified products on agarose gel.

\section{Interpretation of results:}

Analysis of PCR results were based on the presence or absence of specific bands of amplified DNA in the agarose gel (2\%). The length of specific amplified DNA fragments was:

* The specific bands of the rotavirus in the gel were 280 basepairs.

* The specific bands of the rotavirus cDNA(+) in the gel were 280 base pairs.

* The nonspecific bands of the DNA-buffer in the gel were not 280 base pairs.

* Target region: NSP4.

\section{Statistical analysis:}

Data analyses were computer aided. Statistical analysis was done using SPSS (Statistical Package of Social Science) version 18 computer software. Frequency distribution and percentage for selected variables were done first.

The Chi-Square test was used for association between two variables, and the P value (Probability) estimated was considered statistically significant if it's less than 0.05 .

Spearman correlation between screening test and different parameters was done by evaluate $r$ value (correlation coefficient) and $\mathrm{P}$ value (Probability), and an estimate was considered statistically significant if $\mathrm{P}$ value less than 0.05 . $^{(21)}$

\section{Results}

Results presented below are based on statistical analyses of data accumulate throughout the study period.

\section{Detection of Rota virus:}

Polymerase chain reaction:

Table (1) demonstrated that RV-RNA was detected in 46 out of 49 (93.88\%) of the stool specimens by RT-PCR technique, while only $3(6.12 \%)$ specimens were negative. 
Prevalence of Rota virus detection by reverse transcriptase- polymerase chain reaction in stool ..

Table (1): Results of PCR technique for human stool specimens

\begin{tabular}{|c|c|c|c|}
\hline \multicolumn{2}{|c|}{ Results } & Frequency & \% \\
\hline \multirow{2}{*}{$\begin{array}{c}\text { Human } \\
\mathrm{n}=49\end{array}$} & Positive & 46 & 93.88 \\
\cline { 2 - 4 } & Negative & 3 & 6.12 \\
\hline
\end{tabular}

\section{Effects of certain factors on $P C R$ results:}

Results in table (2) showed that the RV-RNA detection rate was (100\%) in three age groups; namely, $>10$ months $-\leq 15$ months, $>15$ months $-\leq 20$ months, and $>20$ months. Whereas, the lowest detection rate was among those $\leq 5$ months $(87.5 \%)$. Nevertheless, the difference among the age groups was statistically insignificant ( $\mathrm{p}=$ $0.833)$.

Table (2): Distribution of PCR results according to age.

\begin{tabular}{|c|c|c|c|c|}
\hline \multirow{2}{*}{ Age (months) } & \multicolumn{3}{|c|}{ Result of PCR } & \multirow{2}{*}{ P Value } \\
\cline { 2 - 4 } & No. positive (\%) & No. negative (\%) & Total & \\
\hline$\leq 5$ months & $7(87.5)$ & $1(12.5)$ & 8 & \multirow{2}{*}{0.833} \\
\hline$>5$ months $-\leq 10$ months & $26(92.85)$ & $2(7.14)$ & 28 & \\
\hline$>10$ months $-\leq 15$ months & $6(100)$ & $0(0.00)$ & 6 & \\
\hline$>15$ months $-\leq 20$ months & $4(100)$ & $0(0.00)$ & 4 & \\
\hline$>20$ months & $3(100)$ & $0(0.00)$ & 3 & \\
\hline Total & 46 & 3 & 49 & \\
\hline
\end{tabular}

The RV-RNA detection rate among female patients was lower $(88.2 \%)$ as compared to that in male patients $(96.8 \%)$. The difference between the two groups was statistically insignificant $(p=0.23)$, table (3).

Table (3): Distribution of PCR results according to sex.

\begin{tabular}{|c|c|c|c|c|}
\hline \multirow{2}{*}{ Sex } & \multicolumn{3}{|c|}{ Result of PCR } & \multirow{2}{*}{ P Value } \\
\cline { 2 - 4 } & No. positive (\%) & No. negative (\%) & Total & \multirow{2}{*}{0} \\
\hline Male & $31(96.87)$ & $1(3.12)$ & 32 & \multirow{2}{*}{0.23} \\
\hline Female & $15(88.23)$ & $2(11.76)$ & 17 & \\
\hline Total & 46 & 3 & 49 & \\
\hline
\end{tabular}

Regarding the effect of residence, The RV-RNA detection rate among urbaneness and ruralnees were $95.6 \%$ and $92.3 \%$ respectively. The difference between the two groups was statistically insignificant $(\mathrm{p}=0.626)$, table $(4)$.

Table (4): Distribution of PCR results according to residence.

\begin{tabular}{|c|c|c|c|c|}
\hline \multirow{2}{*}{ Residence } & \multicolumn{3}{|c|}{ Result of PCR } & \multirow{2}{*}{ P Value } \\
\cline { 2 - 4 } & No. positive (\%) & No. negative (\%) & Total & \multirow{2}{*}{} \\
\hline Urban & $22(95.65)$ & $1(4.34)$ & 23 & \multirow{2}{*}{0.626} \\
\hline Rural & $24(92.30)$ & $2(7.69)$ & 26 & \\
\hline Total & 46 & 3 & 49 & \\
\hline
\end{tabular}

Table (5) revealed that the RV-RNA detection rate was (100\%) in those with bottled feeding compared to $(91.66 \%)$ in those on mixed feeding and $77.77 \%$ in those with breast feeding. The difference between the groups was statistically insignificant $(\mathrm{p}=0.141)$.

Table (5): Distribution of PCR results according to type of feeding $n=49$.

\begin{tabular}{|c|c|c|c|c|}
\hline \multirow{2}{*}{$\begin{array}{c}\text { Type of } \\
\text { feeding }\end{array}$} & No. positive (\%) & No. negative (\%) & Total & \multirow{2}{*}{ P Value } \\
\cline { 2 - 4 } Breast & $7(77.77)$ & $2(22.22$ & 9 & \multirow{2}{*}{0.141} \\
\hline Bottled & $24(100.00)$ & $0(0.00)$ & 24 & \\
\hline Mixed & $11(91.66)$ & $1(8.33)$ & 12 & \\
\hline Total & 42 & 3 & 45 & \\
\hline
\end{tabular}

The RV-RNA detection rate among those consume municipal water as a source of drinking water was (97.22\%), while in those consume bottled water was $(84.61 \%)$, with no statistical difference between the two groups ( $p=$ $0.283)$, table (6). 
Prevalence of Rota virus detection by reverse transcriptase- polymerase chain reaction in stool ..

Table (6): Distribution of PCR results according to source of drinking water.

\begin{tabular}{|c|c|c|c|c|}
\hline \multirow{2}{*}{$\begin{array}{c}\text { source of } \\
\text { drinking water }\end{array}$} & \multicolumn{3}{|c|}{ Result of PCR } & \multirow{2}{*}{ P Value } \\
\hline & No. positive (\%) & No. negative (\%) & Total & \\
\hline Municipal & $35(97.22)$ & $1(2.77)$ & 36 & \multirow{3}{*}{0.283} \\
\hline Bottled & 11(84.61) & $2(15.38)$ & 13 & \\
\hline Total & 46 & 3 & 49 & \\
\hline
\end{tabular}

Table (7) revealed the Spearman's correlation between PCR results and different demographic factors. No significant correlation was found between PCR results with any of the demographic factors.

Table (7): Spearman correlation between PCR test and different parameters in 49 human patients

\begin{tabular}{|c|c|c|}
\hline \multirow{2}{*}{ Parameters } & \multicolumn{2}{|c|}{ PCR test } \\
\cline { 2 - 3 } & $\mathbf{P}$ & 0.747 \\
\hline Age & -0.047 & 0.902 \\
\hline Sex & -0.018 & 0.059 \\
\hline Residence & 0.272 & 0.688 \\
\hline Type of feeding & 0.064 & 0.576 \\
\hline Source of drinking water & 0.082 & \multicolumn{2}{|c|}{} \\
\hline
\end{tabular}

$\mathbf{r}=$ correlation coefficient, $\mathbf{p}=$ probability (level of significance)

\section{Discussion}

Polymerase chain reaction:

In the present study, $93.8 \%$ of patients with acute diarrhea were positive for RV antigen detected by conventional RT-PCR.

These results were agreement with results reported by other worker (22). However, other worker (23) reported a slightly lower infection rate $80.6 \%$ among children $<5$ years of age using RT-PCR technique.

Nevertheless, many studies have yielded variable results (24 and 25) reported an infection rate of $52.7 \%, 58 \%$ respectively among children less than 5 years of age using RT-PCR.

The disparity in the results of the different studies with the present study maybe due to many reasons, imported, the difference in geographical area, volume specimen that included in the study, and the laboratory technique employed for detection of RV.

The present result in this study indicates the importance of using molecular techniques for detection of RV.

\section{Effects of certain factors on RT-PCR results:}

Age:

The results of present showed in this study, the rate of RV-RNA detection by RT-PCR test was (100\%) in ages $>10$ months-> 20 months.

The present results were consistent with results of other workers $(23,24$ and 26) who reported an infection by RV of $98 \%, 94.6 \%$, and $96 \%$ respectively among children less than 22 months of age using RT-PCR test.

$\mathrm{RV}$ is the most causative agent of diarrhea in children under five years of age and the most affected are those under two years of age. The most common sources of infection by RV are the persistence of RV infection in certain newborn nurseries and the high frequency of nosocomial RV infection in hospital, as well as waterborne epidemics, as RVs are resistance to chlorination (27 and 28).

There are many factors that contribute in transmission of virus among these ages and important of these factors are the low health awareness and attention to personal hygiene for people with children, pollution of food and water for consumption by virus and contamination of toys (29).'

\section{Gender:}

The absence of significant difference by RT- PCR test in the infection rate regarding the patients gender also reported by other workers $(30,31,32$ and 33) suggesting the exposure of both sexes to equal risk for infection (34).

\subsubsection{Residence:}

The absence of significant difference by RT-PCR test in the infection rate among patients reside urban and rural area in the present study also reported in other studies (32 and 35), while, (36) reported significantly higher infection rate among patients reside rural area. The infection by rotavirus increases between populations with Low standard of living and that lack of health awareness and health services, as the mortality rate among children in poor countries because of the RV up to $82 \%$ of the total deaths in the world, and many reasons, including malnutrition potential and limited access to the vaccine (37) and thus the children in both societies (rural and urban) are exposed to equal risks of getting infected. .

DOI: $10.9790 / 3008-1201039499 \quad$ www.iosrjournals.org $\quad 97 \mid$ Page


Prevalence of Rota virus detection by reverse transcriptase- polymerase chain reaction in stool ..

Type of feeding:

The current results with respect to rates of infection with RV and how it relates to the type of feeding and using the diagnostic method RT-PCR although it is not significant statistically it shows a rise in infection rates among children fed on breast-mixed industrial compared with the breastfeeding, and these results were consistent with other studies (36, 33 and 38).

Many scientific studies documented that the mother's milk contain factors of natural immunity ( $\operatorname{IgA}$ and $\operatorname{IgG}$ ), and some factors of cellular immunity and their role in the virus inhibitory (39). Mother's milk also contains many other factors as glycoprotein and lactoferine that play a role in preventing or reducing the incidence of the RV (40) .

Note that the samples that were tested by RT-PCR technique was chosen on the basis of random and not biased to ensure the credibility of the work.

\section{Source of drinking water:}

The present study revealed insignificant difference in the infection rate among patients consuming municipal water for drinking compared to other source of water supply by test used for detection RT-PCR. The present results were consistent with almost all previous studies affirming the importance of cotamenated water for transmitting the virus (36 and 41). Of note, several studies have documented the detection of RV from municipal water and other water supply by molecular techniques (42)

RVs are resistance to chlorination, additionally, standard sanitary measure that kill most bacteria and parasites are infective in controlling $\mathrm{RV}(28)$, therefore, the acute gastroenteritis may be due to contamination of municipal water by RV (42).

\subsubsection{Spearman correlation between DAT, ELISA, and RT-PCR tests and different parameters:}

In the present study, the results of RT-PCR revealed no correlation with different parameters included: age, sex, residence, type of feeding, and source of drinking water RV is the most causative agent of diarrhea worldwide (31). RV is transmitted by the mouth through the consumption of water and food contaminated with the virus, and contributes to many of the factors in the transmission of RV, especially in developing countries, as poor health awareness and attention to personal and public hygiene, pollution of water and foods intended for human consumption (29), where RV is responsible for more than 870 thousand new cases and deaths per year among children under five years of age in developing countries (43).

\section{References}

[1]. Bishop, R.F.; Davidson, G.P.; Holmes, I.H. and Ruck, B.J. (1993). Virus particles in epithelial cells of duodenal mucosa from children with acute non-bacterial gastroenteritis. Lancet J. 2(7841): 1281-3.

[2]. Pesavento, J.B.; Crawford, S.E.; Estes, M.K. and Prasad, B.V. (2006). Rotavirus protein: structure and assembly. Curr. Top. Microbiol. Immunol. 309: 189-219.

[3]. Parashar, U.D.; Gibson, C.J.; Bresse, J.S. and Glass,R.I. (2006). Rotavirus and severe childhood diarrhea. Emerg. Infect. Dis. 12: 304-6.

[4]. Santos, N. and Hoshino, Y. (2005). Global distribution of rotavirus serotypes/genotypes and its implication for the development and implementation of an effective rotavirus vaccine. Rev. Med. Virol. 15 (1): 29-56.

5]. O'Ryan, M. (2009). The ever-changing landscape of rotavirus serotypes. Pediatr. Infect. Dis. 28(3): 60-2

[6]. Bishop, R. (2009). Discovery of rotavirus: Implications for child health. J. Gastroenterol. Hepatol. 24 (3): S81-5.

[7]. Bernstein, D.I. (2009). Rotavirus overview. Pediatr. Infect. Dis. J. 28(3): 550-3.

[8]. Black, R.E.; Cousens, S.; Johnson, H.L.; Lawn, J.E.; Rudan, I.; Bassani, D.G.; Jha, P.; Campbell, H.; Walker, C.F.; Cibulskis, R.; Eisele, T.; Liu, L.; Mathers, C. and Child Health Epidemiology Reference Group of WHO and UNICEF. (2010). Global, regional, and national causes of child mortality in 2008: a systematic analysis. Lancet. 375(9730): 1969-87.

[9]. 9- Frieden, T.R.; Jaffe, H.W.; Stephens, J.W.,; Thacker, S.B. and Zaza, S.

(20011). Rotavirus surveillance --worldwide, 2009. Morb. Mortal. Wkly. Rep.60(16): 514-6.

[10]. kapikian, A Z ; Hoshino, Y and Chanock, R M. (2001). Rotaviruses. In: Fields Virology, ${ }^{\text {th }}$ ed.

[11]. Lorrot, M. and Vasseur, M. (2007). Physiopathology of Rotavirus diarrhea. Arch. Pediatr. 14(3): 145-51.

[12]. Lundgren, O. and Svensson, L. (2001). Pathogenesis of rotavirus diarrhea. Microbes Infect. 3(13): 1145-56.

[13]. Ruiz, M.C.; Leon, T.; Diaz, Y. and Michelangeli, F. (2009). Molecular biology of rotavirus entry and replication. Scientific World Journal. 9: 1476-97.

[14]. Borghan, M.A.; Mori, Y.; El-Mahmoudy, A.B.; Ito, N.; Sugiyama, M.; Takewaki, T. and Minamoto, N. (2007). Induction of nitric oxide synthase by rotavirus enterotoxin NSP4: implication for rotavirus pathogenicity. J. Gen. Virol. 88(7): $2064-72$.

[15]. Arcangeletti, M.C.; De Conto, F.; Pinardi, F.; Medici, M.C.; Valcavi, P.; Ferraglia, F.; Motta, F.; Covan, S.; Calderaro, A.; Chezzi, C. and Dettori, G.(2005). Electron microscopy as a reliable tool for rapid and conventional detection of enteric viral agents: a five-year experience report. Acta. Biomed. 76(3):165-70.

[16]. Kohno, H.; Akihara, S.; Nishio, O. and Ushijima, H. (2000). Development of a simple and rapid latex test for rotavirus in stool samples. Pediatr. 42(4): 395-400.

[17]. Pirkooh, A. and Shahrabadi, M. (2007). Development of a latex agglutination method for diagnosis of rotavirus infections. Iran J. Med. 32(2): 100-4.

[18]. Ghazi, H.O.; Khan, M.A.; Telmesani, A.M.; Idress, B. and Mahomed, M.F.(2005). Rotavirus infection in infants and young children in Makkah, Saudi Arabia. J. Pak. Med. Assoc. 55(6): 231-4.

[19]. Ferreira, T.; Becho, M.; Bernardo, A.; et al.(2006). Performance of a latex agglutination test in the diagnosis of acute gastroenteritis by rotavirus. Braz. J. Microbiol. 37(4): 587-9. 
Prevalence of Rota virus detection by reverse transcriptase- polymerase chain reaction in stool ..

[20]. Buesa, J., Colomina, J.; Raga, A.; Villanueva, A. and Prat, J. (1996). Evaluation of reverse transcription and polymerase chain reaction (RT/PCR) for detection of rotaviruses: applications of the assay. Res. Virol. 147: 353-361.

[21]. Niazi, A.D. (2004). Statistical analysis in medical research. $2^{\text {nd }}$ edition.

[22]. Jinda, N.; Patnayak, P.; Hander, C.; Ziegler, A.F. and Goyal, S.M. (2010). Detection and molecular characterization of enteric viruses from poult enteritis syndrome in turkeys. Poultry Science. 89: 217-26.

[23]. Chitambar, S.D.; Tatte, V.S.; Dhogde, R. and Kalrao, V. (2008). High frequency of rotavirus viremia in children with acute gastroenteritis: discordance of strains detected in stool and sera. J. Med. Virol. 80(12): 2169-765.

[24]. Koroglu, M.; Yakupogullari, Y.; Otlu B.; Ozturk, S.; Ozden, M.; Ozer, A.; Sener, K.and Durmaz, R. (2011). A waterborne outbreak of epidemic diarrhea due to group A rotavirus in Malatya, Turkey. New Microbiol. 34(1): 17-24.

[25]. Wible, J.D.; Yolken, R.; Willoughby, R. and Eiden, J. (1991). Improved detection of rotavirus sheeding by polymerase chain reaction. The Lancet. 337(8737): 323-326.

[26]. Xiaoli, L.P.; Bonita, L.; Nasim, B.; Barbara, L.; Jutta, K.; Preiksaitis, A. and Chariotte, C.Y. (2004). Increased detection of rotavirus using real time RT-PCR assay in stool specimens from children with diarrhea. Journal of Medical Virology. 72(3): 496-501.

[27]. Ashbolt, N.J. (2004). Microbial contamination of drinking water and disease outcomes in developing regions. Toxicology. 198(13): 229-38.

[28]. Chandran, A.; Heinzen, R.R.; Santosham, M. and Siberry, G.K.(2006). Nosocomial rotavirus infections: a systematic review. J. Pediatr. 149(4): 441-7.

[29]. Ahmed, M.U.; Kobayashi, N.; Wakuda, M.; Sanekata, T.; Taniguchi, K.; et al. (2004). Genetic analysis of group B human rotaviruses detected in Bangladesh in 2000 and 2001. J. Med. Virol. 72(1): 149-55.

[30]. Hasan, A.Sh.; Al-Azzawi, D.H.; Al-Duliami, A.A. and Al-Azzawi, K.Y. (2011a). Anti-rotavirus IgG seropositivity among healthy popylation and patients with acute diarrhea in Baquba-Diyala province. Iraqi J. Commun. Med.. 24(2): 100-4.

[31]. Carraro, E.; Perosa, A.H.; Siqueira, I.; Pasternak, J. and Martino, M.D. (2008). Rotavirus infection in children a tertiary hospital of Sao Paulo. Brazil. Braz. J. Infect. 12(1): 44-6.

[32]. Al-Kuheli, N.R. (2004). Gastroenteritis viruses among children under five years of age in Al-Ramadi City. M.Sc. thesis. Collage of Medicine Al-Anbar University.

[33]. Al-Falahi, R. (2002). Role of rotavirus gastroenteritis in children under three years of age hospitalized in Al-Ramadi maternity and children, hospital. Diploma thesis. Collage of Medicine, University of Al-Anbar.

[34]. Brooks, G; Carroll, K.C.; Butel, J.S. and Morse, S.A. (2007). Reoviruses, Rotaviruses, and Caliciviruses. In: Medical microbiology. $24^{\text {th }}$ Ed. 2007. McGraw Hill. pp 501-33.

[35]. Kheyami, A.M.; Cunliffe, N.A. and Hart, C.A.(2006). Rotavirus infection in Saudi Arabia. Ann. Saidi Med. 26(3):184-91.

[36]. Hasan, A.Sh.; Al-Duliami, A.A.; Mehdi, Sh. and Al-Azzawi, K.Y. (2011b). The prevalence of rotavirus infection in BaqubaDiyala province. Iraqi J. Commun. Med. 24(3): 200-4.

[38]. Bartlett, C. (1996). An overview of emerging food borne and waterborne disease. East. Medit. Health. J. 2(1): 51-60

[39]. Gupte, S. (1996). Rotaviruses. In: The Short Textbook of Pediatrics(1994). $7^{\text {th }}$ Ed. Jaypee brothers medical publishers. pp 255-290.

[40]. Asensi, M.T.; Martinez-Costa, C. and Buesa, J. (2006). Anti-ratovirus antibodies in human milk: quantification and neutralizing activity. J. Pediatr Gastroenterol Nutr. 42(5): 560-7.

[41]. Newburg, D.S.; Peterson, J.A.; Ruiz, G.M.; Matson, D.O.; Morrow, A.L.; et al. (1998). Rolr of human milk lactaherin in protection against symptomatic rotavirus infection. Lancet. 351: 1160-4.

[42]. Hamza, I.A.; Jurzki, L.; Stang, A.; Sure, K.; Uberla, K. and Wilhelm, M. (2009). Detection of human viruses in rivers of a denselypopulated area in Germany using a virus adsorption elution method optimized for PCR analyses. Water Res. 43(10): 2657-68.

[43]. Scarcella, C.; Carasi, S.; Cadoria, F.; Macchi, L.; Pavan, A.; et al. (2009). An outbreak of viral gastroenteritis linked to municipal water supply, Lombardy, Italy, June, 2009. Euro. Surveill. 14(29): 19274.

[44]. Fischer, T.K.; Viboud, C.; Parashar, U.; et al. (2007). Hospitalization and death from diarrhea and rotavirus among children $<5$ years of age in the United State, 1993-2003. J. Infect. Dis. 195(8): 1117-25. 